\title{
The International Criminal Court and the Issue of Intersectionality-A Conceptual and Legal Framework for Analysis
}

\author{
Gregor Maučec \\ Marie Skłodowska-Curie Postdoctoral Fellow, iCourts-Center of \\ Excellence for International Courts, University of Copenhagen, Faculty \\ of Law, Karen Blixens Plads 16, 2300 Copenhagen S, Denmark \\ gregor.maucec@jur.ku.dk/gregor.mauchec@gmail.com
}

\begin{abstract}
A survey of relevant case law of the International Criminal Court (ICC or Court) reveals inconsistencies, as well as conceptual flaws and limitations in the Court's mainly uni-sectional approach to mass atrocities that involve multiple and intersecting forms discrimination, in particular with regard to the cornerstones of such cases - the identification of the protected groups and their members. This has resulted in discrepancies and low levels of legal protection against intersectional targeting. Such a cautious, selective and inconsistent approach of the ICC to this issue is unsurprising given that the application of intersectionality in practice is a radical and transformative project. Espousing a more consistent and intersectional approach of the ICC in considering mass atrocities against different protected groups and their members, this article discusses the Court's legal framework and major conceptual and statutory concerns surrounding the ICC prosecutor's and judges' enhanced engagement - through more progressive law interpretation — with the phenomena of intersectionality and key concepts related to it. The main purpose of this contribution is thus two-fold: (1) to demonstrate and explain why, in practice, the focus on intersectional dimensions of such situations and cases in their selection, prosecution and adjudication does not interfere with strict adherence to the principle of legality underlying the Rome Statute, and (2) to analyse the legal grounds and avenues for the Court to implement intersectionality when dealing with atrocities involving intersectional discrimination. It is ultimately suggested that Article 21(3) of the Rome Statute offers a proper and solid legal basis for interpreting and applying pertinent international criminal law in light of intersectionality.
\end{abstract}




\section{Keywords}

intersectional discrimination - mass atrocities - protected groups - international criminal court - Rome Statute - international criminal law - nullum crimen sine lege - law interpretation

\section{Introduction}

A review of its jurisprudence on discriminatory violence and targeting shows that the ICC has approached the complex issues of multiple and intersectional discrimination in the context of international crimes inconsistently, occasionally just recognizing them or addressing them only superficially, but more often than not shying away from even dabbling with them. This is true of decisions rendered by both the ICC Prosecutor and ICC judges. In Lubanga, for example, the Court failed to take an instersectional approach to sexual violence perpetrated against young girls. ${ }^{1}$ The sexual abuses the young girls suffered were based on both gender and age discrimination. However, the lack of gender analysis and its intersection with young age of victims by the ICC Prosecutor also prevented international criminal judges to fully understand and appreciate the gravity of these sexual crimes in the context of particular vulnerability of girls in armed conflicts. The ICC thus missed the opportunity to explicitly recognize and take into consideration the fact that young female victims in this particular case faced a unique kind of violation and abuses resulting from the intersection of their gender and age. While underlying rationale for such prosecutorial and judicial uni-sectional tendencies of the Court in interpreting, for example, the law of genocide and of persecution may be manifold, one can identify two specific reasons of legal nature that could explain why generally the Court has been rather conservative, if not evidently ill-disposed, towards addressing this subject matter or treating it in greater detail.

The first such concern of legal relevance has to do with the issue of law interpretation within the constraints of legality principle underlying the legal framework of the Court. The principle of legality requires that crimes be drafted in detail and that judges refrain from making substantive criminal law. Clearly, the drafters of the Rome Statute contemplated the new tribunal as being more conservative. This is visible from very detailed statutory provisions that impose interpretative restraints on the ICC judges, in the first place

1 ICC, Prosecutor v. Lubanga, Case No. ICC-01/o4-01/o6, Trial Chamber, Judgment, 14 March 2012. 
Articles 21 and 22 of the Rome Statute. A comparison with the statutes and practice of ad hoc international criminal tribunals for former Yugoslavia and Rwanda is particularly telling in this regard. A cursory glance at their case law shows that, mostly through identification of customary international norms, they were both very creative and capable of extending considerably the scope and reach of the principles and rules of international criminal law they were entrusted to interpret.

As regards the issue of intersectionality, the ICTY prosecuted and adjudicated a host of cases dealing with wartime sexual violence and rape as a crime against humanity usually intertwined with ethnic/religious/political dimensions of such crimes. Although in some of these cases, the ICTY showed its awareness of the victims gender's connection with other identities/factors/reasons (including race, religion and political opinion) that constituted a discriminatory dimension of such atrocities and consequently adopted interpretation coming close to intersectional understanding of sexual abuse and violence in the context of ethnic conflict, ${ }^{2}$ the Akayesu judgment that the ICTR rendered as early as in 1998 represents a truly landmark and arguably the most far-reaching decision of any international criminal tribunal in this respect. The ICTR trial chamber held in this case that genocide could be perpetrated through rape and other forms of sexual violence, thereby acknowledging the link and overlap between extreme forms of gender and racial discrimination. ${ }^{3}$ According to this ICTR judgment, acts of rape and sexual violence can 'constitute genocide in the same way as any other act as long as they were committed with specific intent to destroy, in whole or in part, a particular group, targeted as such'. ${ }^{4}$ The ICTR trial judges moreover underscored that Tutsi women were subjected to sexual violence because they were Tutsi, this is, because of their ethnic identity. In other words, sexual violence was a step in the process of destruction of the Tutsi group. ${ }^{5}$ In Akayesu, the ICTR therefore made a very strong case for

See, for example, ICTY, Prosecutor v. Dragoljub Kunarac et al., Case Nos. IT-96-23-T \& IT-96-23/1-T, Trial Chamber, Judgment, 22 February 20o1, para. 654. ICTY, Prosecutor v. Dragoljub Kunarac et al., Case Nos. IT-96-23 \& IT-96-23/1-A, Appeals Chamber, Judgment, 12 June 2002, para. 153.ICTY, Prosector v. Kvočka et al, Case No. IT-98-30/1-T, Trial Chamber, Judgment, 2 November 2001, para. 560. This finding was confirmed on appeal, ICTY, Prosector v. Kvočka et al., Case No. IT-98-30/1-A, Appeals Chamber, Judgment, 28 February 2005, para. 370. ICTY, Prosecutor v. Brđanin, Case No. IT-99-36-T, Trial Chamber, Judgment, 1 September 2004, paras 1011, 1013 and 1050. ICTY, Prosecutor v. Đorđević, Case No. IT-0587/1-A, Appeals Chamber, judgment, 27 January 2014, para. 887. ICTR, Prosecutor v. Akayesu, Case No. ICTR-96-4-T, Trial Chamber, Judgment, 2 September 1998.

$4 \quad$ Ibid., para. 731.

$5 \quad$ Ibid., para. 732. 
considering the matters of political violence and gender together with, and not separately from, the issues of the rights of ethnic minorities, thus clearly pointing to the need for intersectional consideration of atrocities involving elements of discrimination, such as genocide, apartheid, persecution, and sexual and gender-based crimes.

These developments in the case law of ICTY and ICTR, though not providing any further insights into the intersecting discriminatory dimensions of the crimes prosecuted than just alluding to or acknowledging the existence of such situations, are nevertheless ground-breaking, for they paved the way for further development of international criminal jurisprudence towards firm recognition of rape as a form of genocide and the relationship between sexual violence and ethnicity. Recognizing the ethnic and religious dimensions of sexual abuses and gender-based violence enabled both the ICTY and the ICTR to place rape within the category of genocidal acts and acts constituting crimes against humanity. This new way of looking at sexual abuse in conflict situations was especially important for the enhanced protection of women and girls belonging to ethnic and religious minorities. Presumably, in view of such a dynamic and purposive, but also more accurate, fair and inclusive interpretation of intersectional targeting by ad hoc international criminal tribunals, the main concern for the ICC seems to be the fear that placing greater emphasis on the issues of intersectionality would diverge the Court's focus from full respect for the principle of legality, if not offend it. In particular, there seems to be a tension between interpreting relevant substantive international criminal law in the context of intersectionality and one of the essential components of the principle of legality - that is, that every uncertainty must be interpreted in favour of the accused (in dubio pro reo).

Another reason for non-implementation or fairly limited application of intersectionality by the Court in its pertinent case law may lie in the question of what legal basis the ICC can persuasively invoke when implementing the intersectionality perspectives through its decisions on mass atrocities involving protected groups. In other words, how could the concept of intersectionality be brought into the Court's legal framework and reasoning? Closely related to the question of adequate and cogent legal basis for more intersectional consideration of certain mass crimes by the Court is also an important conceptual issue; as the ICC is not a human rights court, its prosecutor and judges may be more careful in considering how far they should go in developing its jurisprudence on the issue of intersectional discrimination which is predominantly victims-oriented. By nature, in the context of mass atrocities the notion of intersectionality is mostly concerned with specific harms caused to victims of intersectional targeting. 
Focusing on these lines of inquiry, the article offers basic conceptual framework for addressing concerns surrounding the issue of intersectionality in international criminal law in view of recent developments at the ICC. Such a framework recognizes complex identities of members of the protected groups as victims of mass atrocities and serious human rights violations, and incorporates intersectionality in both international criminal law discourse and adjudication of international crimes. By employing it, the ICC prosecutor and judges should be able to better address difficult realities of those victims of mass crimes whose identities fall within more than one protected or vulnerable group. This is necessary to advance the understanding, interpretation and development of international criminal law.

Correctly defining the term 'intersectional' discrimination as a special type of multiple discrimination is not only desirable, but also necessary for international criminal law to tackle it accordingly within the core international crimes. For the purposes of my analysis, the notion of 'intersectional discrimination' is applied in its narrower sense to refer to a situation in which there is a specific type of discrimination, in which two or more grounds of discrimination interact concurrently, thus contributing to unique experiences of discrimination. Intersectional discrimination occurs when, for instance, a person with an ethnic minority background or associated to such a background suffers discriminatory targeting, for example, in the form persecution on the grounds of ethnic origin, combined with, colour, sex, language, religion, political or other opinion, sexual orientation, gender expression, age or other status.

Perhaps the most comprehensive and inclusive interpretation of the prohibition of discrimination that is based on intersectionality-logic is contained in the CRPD Committee's General Comment on women and girls with disabilities:

The concept of intersectional discrimination recognizes that individuals do not experience discrimination as members of a homogenous group but, rather, as individuals with multidimensional layers of identities, statuses and life circumstances. It acknowledges the lived realities and experiences of heightened disadvantage of individuals caused by multiple and intersecting forms of discrimination, which requires targeted measures to be taken with respect to ... the enforceability of non-discrimination policies and the provision of effective remedies. ${ }^{6}$ 
Significantly, this definition articulates that intersectional discrimination comprises several layers of discrimination based on various grounds whose common interaction gives rise to new forms of discrimination that are unique and cannot be accurately understood by simply describing them as double, triple, or multiple discrimination. As such, the definition also underlines the main advantages of intersectional consideration compared to applying a single-strand analysis. Firstly, it specifies that intersectional discrimination is a form of multiple discrimination based on the interlinking of various identities. Secondly, it posits that, unlike in the case of additive discrimination, the grounds of discrimination are inextricably linked such that it is impossible to separate them in order to tell which part of the discrimination is based on a particular ground. ${ }^{7}$ Thirdly, it emphasizes that intersectionality-based understanding of inequalities is 'useful to uncover experiences that may remain invisible in the single-axis analysis, and to account for the complexity of human experiences at the intersection of sex, gender, age, sexual orientation, ethnicity, or cultural or religious backgrounds'. ${ }^{8}$ Fourthly, this definition acknowledges that multiple discrimination and, in particular, intersectional discrimination has unique and specific impact on individuals. Hence, it merits special and thorough consideration and appropriate remedying.

In order to address the above core legal and also conceptual questions, this article is structured as follows. The second section provides a conceptual framework for understanding and analysing intersectional dimensions of mass atrocities against different protected and vulnerable groups and for identifying the ways for the Court to integrate and mainstream intersectional interpretations into its legal reasoning. In so doing, it discusses the conceptual relevance of intersectionality to international criminal law. The third section looks more closely at seemingly conflicting relationship between intersectional consideration of mass atrocities by the Court and its strict implementation of the principle of legality. The fourth section turns to consider a proper legal basis for the Court to persuasively rely on in dealing with the phenomena of intersectional discrimination in the context of core international crimes that discriminatorily target different protected groups and their members. Lastly, the fifth section offers some general conclusions in light of the main research questions.

\footnotetext{
7 Sandra Fredman, Intersectional Discrimination in EU Gender Equality and NonDiscrimination Law, (European Commission, Brussels, 2016), p. 120. 
Conceptually, mass atrocities such as genocide, apartheid, persecution on protected grounds, sexual and gender-based crimes and other atrocities of similar gravity directed at protected groups (usually, but not exclusively, committed in armed conflicts), often have their root causes in ethnic tensions, pervasive discriminatory practices, as well as concomitant hatred towards and suppression of targeted groups. This entails that there is a critical linkage between mass atrocities against certain groups and their members because of their protected identities and unlawful discrimination and victimization they regularly face. What complicates the matter further is the fact that certain more vulnerable members within the specifically protected groups of population (such as children, women, elderly, Christians, Muslims, homosexuals, etc.) and communities who are politically, economically or socially most marginalized are particularly targeted and victimized in such situations.

In considering the application of intersectionality to international criminal law, it is first necessary to clarify the purposes of anti-discrimination law, as well as the nature and content of intersectional discrimination. For certain individuals and population groups that experience multiple and intersecting forms of discrimination that exacerbate exclusion in both law and practice, the full enjoyment of human rights is further restricted. To be able to address intersectionality, a coherent body of multi-ground non-discrimination law needs to be construed as aiming to protect individuals in relation to their ascribed group membership(s), rather than groups as such. ${ }^{9}$ Intersectional discrimination is a form of multiple discrimination - this is, discrimination based on more than one ground - which by moving beyond simply cumulative effects and capturing synergistic effects of such discrimination aims to ensure substantive equality. That said, not every multiple discrimination is necessarily associated with intersectionality.

Single-axis models of discrimination law that recognize only monistic identity categories, while able to ensure formal equality and procedural fairness, are particularly ill-suited to achieve substantive equality. They deny the existence of meaningful connections between various identity categories or intersectional variations within a particular category, thus leaving those with complex identities (for example, young Muslim girls) outside the scope of legal protection. In the same vein, intersectional approach to discrimination law, on the other hand, attempts to grasp the complex and multifarious nature of

9 Dagmar Schiek, 'On uses, mis-uses and non-uses of intersectionality before the Court of Justice (EU)', 18 International Journal of Discrimination and the Law (2018) 82-103, p. 86. 
identity and address the particular vulnerability of minority women and other individuals from minority groups where the vulnerability results from a complex interplay of sexism, racism, ageism, etc. In the same vein, applying intersectionality to international criminal law can offer an adequate analysis of the lived experiences of intersectional identity in the context of atrocity crimes of discriminatory character.

The following situation of intersectional (this is, combined gender-based, religious and racial) oppression and persecution in Mali between 2012 and 2013 can serve as a case in point. In fostering of a policy designed by the armed groups Al-Qaida in the Islamic Maghreb ("AQIM") and Ansar Dine, a widespread and systematic attack was carried out against the civilian population of Timbuktu, including torturing, raping and persecuting especially those with intersecting identities. As suggested in the Al Hassan Warant Decision, the said armed groups wished to impose on civilian population their authority and their new religious order, involving strict rules, prohibitions and punishments. This policy was 'calculated to oppress anyone who failed to demonstrate the required religiosity, in particular women and girls. ${ }^{10}$ As a result, black women not strictly adhering to required religious practices were targeted most intensively and most frequently of all the groups and communities under oppression. Because of their overlapping, that is, intersecting identities (gender, race and religion) they suffered the most extreme forms of violence and abuse. These factors substantially transformed the kind of discrimination that these victims were subjected to. Such synergetic effects resulting from an intersection of two or more reasons for discrimination require more nuanced and sophisticated consideration of mass atrocities involving different protected groups and their members. This unique and complex type of discrimination caused by multiple reasons of discrimination was more than simply a sum of several factors of discrimination and was, as such, the underlying reason for persecution and other mass abuses against women and other particularly vulnerable groups.

Intersectionality, while involving multiple grounds of discrimination, constitutes a wholly different and distinct kind of discrimination that is deep-seated, more puzzling and intricate. It recognizes unequal treatment of different groups and their members as a 'many layered blanket of oppression.'11

10 ICC, Prosecutor v. Al Hassan, Case No. ICC-01/12-01/18, Pre-Trial Chamber, Decision on the Prosecutor's Application for the Issuance of a Warrant of Arrest for Al Hassan Ag Abdoul Aziz Ag Mohamed Ag Mahmoud, 22 May 2018, para. 6o. See also Guénaël Mettraux, International Crimes: Law and Practice, Volume II: Crimes Against Humanity (Oxford University Press, Oxford, 2020), p. 280.

11 Nira Yuval-Davies, 'Intersectionality and Feminist Politics', 13(3) European Journal of Women's Studies (2006) 193-209, p. 196. 
Intersectional approach to discrimination enables us to shift the focus from a difference of quantity to a difference of quality. In the above situation in Mali, a crucial interrelationships can be observed between tenacious discriminatory and humiliating treatment and violence against women and violations of their fundamental rights. In this and other similar situations, it is therefore essential to take an intersectional approach to considering mass atrocities involving discrimination, in order to acknowledge and better understand the specific character of violence, oppression and injustices that dark skin women and girls suffered. Such offensive and outrageous practices of discrimination taking place in the context of conflict and violence can only be properly understood in terms of the 'confluence' of the various forms and reasons of discrimination that underlay such persecutory acts.

It is important to note that it was the intersection of different forms and reasons of discrimination that generated a very particular and specific harm suffered by the victims of mass abuses. This unique harm and injustice can only be properly assessed in view of the lived intersectional experience of the victims who, historically, have been discriminated against for more than one prohibited ground of discrimination. During a widespread and systematic attack against civilians in Mali certain members of the protected groups suffered multiple forms of discrimination derived from and associated with a number of factors such as being a woman (gender discrimination), a person not practising the imposed religion (religious discrimination), a person of colour (racial discrimination), and a minor or an elderly (age discrimination). These aspects made these specific groups of people more vulnerable and exacerbated the harm that they suffered. The case of Mali illustrates that multiple gender-, race-, religion- and age-related stigmatization did not affect everyone in the same way and that the impact of overall violence and mass abuses was more severe on members of the said vulnerable groups. It reveals that simultaneous operation and interaction between several different systems of oppression, namely racism, sexism and ageism, substantially contributed to the agony and suffering of the victims. Hence, pursuing a more intersectional approach to discrimination in the context of mass atrocities can help contest the traditional understanding of a privileged place reserved for one protected group and their members. ${ }^{12}$ Employing intersectional methods of analysis in consideration of mass atrocities enables international criminal law to contend with the intricacy of intersecting factors and identities, as well as particularly harmful nature of intersectional discrimination more efficiently. 
A further analysis of the topic necessitates also more detailed explanation of the concept of intersectionality as appearing in the academic literature. The word 'intersectionality' has its origins in black feminist theory. It was coined by Kimberle Crenshaw, an American legal theorist, whose famous scholarly paper criticized both race theory and feminist theory for their inability to tackle the particularities of intersectional discrimination due to their overly narrow focus on race and gender. ${ }^{13}$ In theoretical studies on the subject, the idea of 'intersectionality' has been mostly used to attend to the phenomena and situations where two or more forms of discrimination overlap. The concept is applied in these studies to describe more accurately the focus of the analysis in dealing with two or more axes (sections) of power and domination. ${ }^{14}$

In her seminal writing, Crenshaw propounded a novel approach to considering black women's lived experiences of intersectional discrimination to fathom the reality of multiple and overlapping reasons for their subordination consisting of their race, gender, and class. Eventually, the concept of intersectionality was extended beyond its roots in black feminist thought to capture the relationships between multiple and intersecting identities in social relations. Intersectional analysis has thus been employed in the mainstream literature to examine and better grasp the multiple identities of other disadvantaged groups similarly located at several intersections of discrimination and subordination (for example, the intersecting identities and locations of Latinos, Asian Americans, etc.). ${ }^{15}$

Every person is the product of intersecting identities, including gender, race, religion, sexual orientation, age, etc. protected by discrimination law. Intersectionality highlights inseparability of such individual's multiple characteristics. Put otherwise, intersectionality counters group generalizations to emphasize unique and more complex experiences and locations of subordination with regard to some individuals within a certain group..$^{16}$ According to Keina Yoshida, intersectionality highlights a 'holistic approach' in guaranteeing the freedom from discrimination and violence. ${ }^{17}$ The intersectionality

13 Kimberle Crenshaw, 'Demarginalizing the Intersection of Race and Sex: A Black Feminist Critique of Antidiscrimination Doctrine, Feminist Theory and Antiracist Politics', 1 University of Chicago Legal Forum (1989) 139-167, pp. 150-152.

14 Brenda Cossman, 'Intersectionality', in Peter Cane and Joanne Conaghan (eds.), The New Oxford Companion to Law (Oxford University Press, Oxford, 2008), p. 632.

15 Ibid.

16 Aisha Nicole Davis, 'Intersectionality and International Law: Recognizing Complex Identities on the Global Stage', 28(1) Harvard Human Rights Journal (2015) 205-243, p. 213.

17 Keina Yoshida, 'Towards Intersectionality in the European Court of Human Rights: The Case of B.S. v Spain', 21 Feminist Legal Studies (2013) 195-204, p. 196. 
discourse aims to correct uni-sectional and additive analytical approaches to multiple and intersecting forms of discrimination. In so doing, it seeks to fill in the gaps created by perceiving different discrimination grounds such as race, religion, gender, sexual orientation, age, etc. as mutually exclusive. ${ }^{18}$ As Ben Smith has noted, intersectionality serves as a means for the examination of the root causes of inequality'. ${ }^{19}$ The following definition probably best describes the importance of examining the intersection of multiple forms of discrimination, including their root causes from gender and other perspectives:

The idea of 'intersectionality' seeks to capture both the structural and dynamic consequences of the interaction between two or more forms of discrimination or systems of subordination. It specifically addresses the manner in which racism, patriarchy, economic disadvantages and other discriminatory systems contribute to create layers of inequality that structures the relative positions of women and men, races and other groups. ${ }^{20}$

In a similar vein, judge Poisot at Inter-American Court of Human Rights underlined two distinctive features of intersectional discrimination: (1) the discrimination factors are 'analytically inseparable because the experience of discrimination cannot be disaggregated into different reasons' ${ }^{21}$ meaning that 'the experience is transformed by the interaction, ${ }^{22}$ and (2) intersecting reasons for discrimination entail 'different qualitative experiences, creating consequences for those affected in ways that are different from the consequences suffered by those who are subject to only one form of discrimination.' ${ }^{23}$ Therefore, intersectional discrimination creates 'a different and unique harm, which is distinct from the discriminations assessed separately'. ${ }^{24}$

18 Davis, supra note 16, p. 208.

19 Smith, supra note 12, p. 77.

20 United Nations Diversion for the Advancement of Women, Office of the High Commissioner for Human Rights and United Nations Development Fund for Women, Gender and Racial Discrimination, Report of the Expert Group Meeting, Zagreb, Croatia, 21-24 November 200o, at section $\operatorname{III}(\mathrm{C})$.

IACtHR, Gonzales Lluy et al. v Ecuador, Preliminary objections, merits, reparations, and costs, Judgment, 1 September 2015, Concurring opinion of Judge Eduardo Ferrer Mac-Gregor Poisot, para. 11.

22 Ibid.

23 Ibid.

$24 \quad$ Ibid., para. 12. 
In scholarly debate, intersectionality — as a social and legal concept-has also been the subject of significant theoretical critique, notwithstanding its meaningful potential for developing more robust, nuanced and sophisticated analyses of subordination. It has been noted, for example, that intersectionality can result in the phenomenon of 'infinite regress'. ${ }^{25}$ In other words, because of the multiplication of identities, individuals may become 'infinitely distinguishable from each other'. ${ }^{26}$ Richard Delgado has posited, in this particular context, that intersectionality, if applied limitlessly, may generate identity subcategories ad infinitum. ${ }^{27}$ The concept of intersectionality has moreover been criticized for having mostly considered the 'question of identity and difference',28 while missing to provide 'more systemic analyses of the operation of power'. ${ }^{29}$ Some other scholars have submitted that intersectionality theories are only of limited relevance to both discrimination law and policy, ${ }^{30}$ thus posing a particular challenge for legal proceedings. ${ }^{31}$ For instance, Joanne Conaghan has argued that the rigidity and inflexibility of law as a system of rules and principles prevents the theory of instersectionality from capturing the difficulties of the complex identities. ${ }^{32}$ This latter argument may be of particular importance for criminal law system (both at national and international level) which may be viewed as being too rigid (because of the principle of legality) to be tailored to encompassing the phenomena of intersectionality in the context of mass atrocities.

All these critiques, however, appear to ignore an important fact that laws and policies can be expanded, re-framed or otherwise amended so as to include an intersectional analysis of acts of discrimination..$^{33}$ It has further

25 Maike Isaac and Olga Jurasz, 'Towards an Intersectional Understanding of Conflict-Related Sexual Violence: Gender, Sexuality, and Ethnicity at the ICTY', 18(5) International Criminal Law Review (2018) 853-882, p. 855 .

26 Ibid.

27 Richard Delgado, 'Rodrigo's Reconsideration: Intersectionality and the Future of Critical Race Theory', 96 Iowa Law Review (2011) 1247, pp. 1263-1266.

$28 \quad$ Ibid.

$29 \quad$ Ibid.

$30 \quad$ Ibid., p. 1264.

$31 \quad$ Fredman, supra note 7 , pp. 8o-85.

32 Joanne Conaghan, 'Intersectionality and the Feminist Project in Law', in Emily Grabham et al. (eds.), Intersectionality and Beyond: Law, Power and the Politics of Location (RoutledgeCavendish, London, 2008) 21- 49, p. 24.

33 For example, provisions on combined discrimination (dual characteristics) in the UK Equality Act 2010 bespeak of a noteworthy, though limited attempt of British legislator to embrace an intersectional approach to double discrimination. Likewise, the Ontario Human Rights Commission in Canada issued a discussion paper about consolidating an 
been postulated that because of the intricacies and challenges it represents for discrimination law and policy, the concept of intersectionality should be replaced by other more appropriate notions such as 'capacious grounds' and 'horizontal inequalities'. ${ }^{34}$ In addition, certain post-intersectionality concepts, including co-synthesis and symbiosis, have appeared as practicable substitutes aimed at weakening intersectionality's conceptual association with identity categories and capturing 'the ways in which the very categories themselves are not fixed and stable, but mutually producing and shifting over time and place. ${ }^{35}$

In international human rights jurisprudence on intersectional discrimination, piecemeal considerations of the intersectionality issue have substantially influenced and shaped the way the human rights treaty body case law on sex discrimination has developed. More particularly, through the lens of intersectionality, these bodies were able to 're-conceptualize discrimination not as an event but as a process. ${ }^{36}$ Notwithstanding the recognition that intersectional discrimination has slowly gained over the years in the explicit and implicit references across the practice of international human rights treaty bodies, some writers have noted that 'the effectiveness of the concept remained uncertain'. ${ }^{37}$ Moreover, several criticisms have been levelled at international human rights practice concerning the phenomenon of intersectional discrimination. The first such critique relates to the problem of treating women as a monolithic group caused by the inclusion of both men and women as analytical subjects in any given substantive area. This is also the main reason why Committees like the Committee on the Elimination of Racial Discrimination (CERD), while adding women as an analytical category, have failed to recognize that these

intersectional interpretation of discrimination. Ontario Human Rights Commission, An Intersectional Approach to Discrimination: Addressing Multiple Grounds in Human Rights Claims, www.ohrc.on.ca/sites/default/files/attachments/An_intersectional_approach_to_ discrimination\%3A_Addressing_multiple_grounds_in_human_rights_claims.pdf, accessed 27 April 2020.

34 Fredman, supra note 7 , pp. $35^{-36}$ and $69^{-70}$. See also, Frances Stewart, 'Horizontal inequalities and intersectionality', in Emma Samman and José Manuel Roche, Group inequality and intersectionality (2014), en.unesco.org/inclusivepolicylab/sites/default/files/ publication/document/2017/2/Group\%2oinequality\%2ointersectionality.pdf, accessed 28 December 2020, pp. 10-13.

35 Cossman, supra note 14.

36 Pok Yin S. Chow, 'Has Intersectionality Reached its Limits? Intersectionality in the UN Human Rights Treaty Body Practice and the Issue of Ambivalence', 16(3) Human Rights Law Review (2016) 453-481, p. 480.

37 Ibid., p. 454. For a similar observation, see also Timo Makkonen, Multiple, Compound and Intersectional Discrimination: Bringing the Experiences of the Most Marginalized to the Fore (2002), p. 5 . 
women have been subjected to discrimination because of their intersecting identities.

Another problem with gender mainstreaming that international mechanisms for the protection of human rights have fostered is that gender dimensions are being regularly examined in all cases of race-, ethnicity- or disability-based discrimination, whereas factors like race, disability, religion and age are not being considered when dealing with sex discrimination cases. It is also problematic that recommendations issued by the Committee on the Elimination of Discrimination against Women (CEDAW) do not directly confront women's intersecting identities, but they treat them within minority groups as a subcategory. ${ }^{38}$ Such approach is deficient in that it treats cases involving both racial or ethnic discrimination and gender discrimination from a perspective that views women's claims as less than "pure". 39 Put otherwise, for women who experience human rights violations based on the intersection of their ethnicity or race and gender 'the inquiry is built on a framework created for purely racial analysis' $^{\prime 0}$ As a result, the examination of how gender operates in the frame of these ethnic or racial identities is only of secondary importance. ${ }^{41}$

Another aspect of the overall critique of the existing international jurisprudence on the subject is that those international human rights treaty bodies that have applied intersectionality in their practice have preferred to consider it as an inter-categorical phenomenon. As Pok Yin S. Chow explains, such an approach prevents the concept of intersectionality from being used to its full potential. ${ }^{42}$ This is because it tends to regard multiple grounds as necessarily contributing to accumulative forms of oppression and the resultant discrimination. ${ }^{43}$ Thus, it may lead to a misperception that intersectional discrimination can successfully be dealt with by simply reducing it to 'a form of "additive exercise"."44 According to Chow, this limited understanding and examination of intersectional discrimination can be overcome by adopting an intra-categorical perspective of intersectionality analysis. ${ }^{45}$ Such a conceptual shift in our understanding of intersectionality enables us to examine 'how discourses are produced, reproduced, experienced and resisted'. ${ }^{46}$

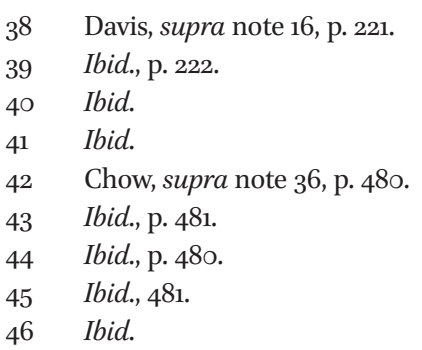


Last but not least, concerns have also been raised about the divergent and fragmented body of international jurisprudence concerning interpretation of intersectional discrimination. In response to this line of criticism, some commentators have pointed to 'joint action by all of the human rights treaty bodies in the development of a common interpretation of the non-discrimination guarantees that are contained in each of the core human rights treaties' ${ }^{\prime 4}$ as one of the possible paths towards improved coordination and consistence in international human rights practice on the subject.

In reaction to the above criticisms, conceptions and arguments about the issue of intersectionality, Iyiola Solanke has claimed that the so-called 'mosaic' theory should be employed to capture the dynamic interactions and synergetic effects crucial to the concept. This theory implies that 'the whole is more than the sum of its parts', ${ }^{48}$ or as another eminent writer has noted, the most important message arising from the intersectionality thesis is that an individual is more than the sum of their parts. ${ }^{49}$ Mosaic theory prioritizes the qualitative over quantitative difference between intersectional and other forms of multiple discrimination, such as cumulative (additive) discrimination. Solanke has also suggested replacing the logic of immutability typical of discrimination law and policy with the idea of stigma and stereotypes, as these are contextually constructed. Stigma- and stereotypes-based logic does not concentrate on the individual. Such an anti-stereotyping reasoning instead focuses on negative meanings and connotations that the society associates with individual characteristics. ${ }^{50}$ Taking the above key aspects into account, inclusive and substantive equality as a tool to fight against stereotyping, prejudice and violence, while at the same time highlighting human dignity, should be regarded as the most appropriate and effective way of dealing with the many complexities of intersectional discrimination..$^{51}$

Intersectional (this is, raced and gendered) oppression that usually targets ethnic women too often escalates into sexual aggression, violence and mass abuses against women and girls, especially during ethnic conflicts.

47 Ivona Truscan and Joanna Bourke-Martignoni, 'International Human Rights Law and Intersectional Discrimination', 16 The Equal Rights Review (2016) 103-131, 129.

48 Iyiola Solanke, Tackling multiple discrimination: Delivering equality in the 21st century (2011), blogs.lse.ac.uk/equityDiversityInclusion/2011/og/tackling-multiple-discriminationdelivering-equality-in-the-21st-century/, accessed 27 April 2020. Gerard Quinn, 'Reflections on the Value of Intersectionality to the Development of Non-Discrimination Law', 16 The Equal Rights Review (2016) 63-72, p. 71.

$50 \quad$ Solanke, supra note 48.

$5^{1}$ CRPD, General Comment No 6 on equality and non-discrimination (Article 5), CRPD/C/GC/6, 9 March 2018, para. 11. 
This happened, for example, in Rwandan genocide where racial and gender stereotypes incited race- and gender-based hatred, violence and, ultimately, mass atrocities against Tutsi women. ${ }^{52}$ Against this backdrop, I argue that the approach that concentrates on stereotypes and prejudice can offer a mode of thinking that more effectively addresses both the particularities of intersectional discrimination, as well as other forms of persistent inequality. In particular, this holds true of the most extreme and inhuman crimes resulting from such prejudice and stereotypes, including genocide, apartheid, persecution and various gender-specific crimes.

The theory of intersectionality can thus shed a new light on the socio-legal conception of multiple, compound and intersecting forms of discrimination (racial, religious, gender-based and other discrimination) in international criminal law, as it 'explains the multiple dimensions of discrimination that underpin situations of social abuse. ${ }^{53}$ Moreover, pursuing an intersectional approach towards prosecuting and adjudicating mass atrocities against protected groups should allow the Court to come up with a more accurate, fair and nuanced legal interpretations of such abuses, thus challenging 'the assumption of homogeneity of victims which is commonly reproduced in judgments of international criminal courts and tribunals. ${ }^{4}$ This broader understanding can help the ICC address the root causes of such violent acts and human rights abuses, thereby establishing and developing a jurisprudence based on the recognition of compound and intersecting forms of discrimination that are part and parcel of certain atrocity crimes.

Mass abuses against vulnerable groups of population cannot be treated in isolation, but require a rights-based approach that recognizes the indivisibility and interdependence of rights. Such a rights-based approach is focused on upholding the dignity and integrity of the individual, whereby the concept of dignity requires that every person is recognized, respected and protected as a rights holder. By interpreting and applying international criminal law in a way that utilizes intersectionality, the ICC can make in these areas important jurisprudential contributions with far-reaching legal and factual implications. For example, the realities and needs of those who have been persecuted or otherwise discriminatory targeted during ethnic or religious conflict can be better

\footnotetext{
$5^{2}$ For a more comprehensive discussion of this issue, see Llezlie L. Green, 'Gender Hate Propaganda and Sexual Violence in the Rwandan Genocide: An Argument for Intersectionality in International Law', 33(3) Columbia Human Rights Law Review (20012002) 733-776.

53 Ana Martin Beringola, 'Intersectionality: A Tool for the Gender Analysis of Sexual Violence at the ICC', 9(2) Amsterdam Law Forum (2017) 84-109, p. 85.

54 Isaac and Jurasz, supra note 25, p. 855 .
} 
addressed if their status and rights are seen through the lens of intersectionality. Intersectional approach to international crimes of discrimination accounts for the diverse needs and interests of women and other particularly vulnerable groups (including children, elderly, homosexuals and people of minority religions), as well as for difficulties that they face. Consequently, these protected groups and individuals are no longer viewed as falling in the gaps between race/ethnicity, gender, age, religion, sexual orientation or other identity category as a reason for intersectional discrimination. This implies that the ICC should vigorously pursue measures to tackle multiple, compound and intersecting forms of discrimination and social inequalities through its application and interpretation of international criminal law.

Addressing intersectional inequalities through the law and practice of the ICC requires, first of all, that applicable law properly responds to oppression, maltreatment and mass abuses as experienced in reality. The Court's enhanced determination to interpret the relevant law in light of intersectional dimensions of mass atrocities can more effectively advance the interest of international justice, because such a refined legal interpretation has the potential to reverse the underlying reasons for targeting and abusing groups and individuals on multiple and intersecting grounds of discrimination. This entails that intersectional perspective on mass atrocities motivated by discrimination against the protected groups can be far more informative and insightful for the Court than traditional uni-sectional approach to human rights abuses. In particular, intersectionality analysis can help the Court recognize and more accurately assess the complex discriminatory motive behind heinous crimes involving the protected groups and their members as well as the extreme vulnerability of victims of such atrocities.

As already noted in the introductory section, however, one may wonder what the conceptual value of all this discussion is, given that, after all, the ICC itself is not a human rights court. Indeed, the Court's primary mission is that of enforcement, that is, to determine the guilt or innocence of individuals accused of core international crimes and to impose sentences on persons within the limits set forth in the Rome Statute. The crux of the Court's role thus lies in enforcing and inducing compliance with specific norms of international law aimed at preventing and outlawing mass violence and atrocity crimes. ${ }^{55}$

Sang-Hyun Song, 'The Role of the International Criminal Court in Ending Impunity and Establishing the Rule of Law', UN Chronicle, www.un.org/en/chronicle/article/roleinternational-criminal-court-ending-impunity-and-establishing-rule-law, accessed 29 December 2020. 
This raises the question to what extent, if at all, the Court should implement intersectionality in its decisions and accordingly develop its jurisprudence on intersectional discrimination in the context of mass atrocities.

Naturally, sympathy for the victims' unfathomable misery and grievances and the Court's efforts to end impunity are potent incentives for the ICC Prosecutor and judges when making their decisions. However, both goals pursued by the Court - this is, combating impunity and repairing harm to victims - can simply be understood as being part of broader efforts to ensure fair trials for those accused of very serious crimes. Considerations about victims' rights and interests, while certainly relevant, should not trump the rights of the accused. In order for the ICC to have the legal and moral authority to pass legal and moral judgment on individuals facing such serious allegations as crimes of genocide and persecution, it is, of course, essential to carefully observe the fairness of international criminal trials and the rights of the accused. But this overriding goal of international criminal justice, in my view, does not preclude the Court from considering also human rights of particularly vulnerable sections of civilian population-including children, women and elderly - especially if they belong to groups and communities legally protected from discrimination. Rendering justice means meting out justice to both accused persons and victims. Hence, the Court should seek the ways to enforce the enhanced protection of victims and vulnerable groups through prosecutorial and judicial decisions, inter alia, by adopting intersectional interpretations.

The Court's proceedings normally focus on the accused, but ICC judges' common consideration should also be how their decisions may affect the status and rights of victims, including those who suffered mass abuses because of their intersecting identities. In other words, the Court needs to pronounce itself also on the aspects of restorative and retributive justice. This being said, beside race and gender, intersectional theory should include a number of other grounds of discrimination, also in the context of international crimes. Given its flexibility and adaptability to new reasons/factors of discrimination, intersectional approach to discrimination in the international criminal law discourse and adjudication can provide a successful normative framework for integrating and mainstreaming societal, economic, political, cultural and historical aspects into the protected groups' rights enforcement. As such, it can considerably contribute to the Court's jurisprudential developments in the future cases concerning minorities' and other vulnerable groups' protection. 
On Applying Intersectionality to the ICc Law and the Principle of Legality-Explanations for the Adoption of Intersectionality by Means of Flexible Tools of Interpretation

Following the foregoing conceptual considerations, this article further queries whether, in view of the Rome Statute's requirement for strict compliance with the principle of legality in practice, the proposal for strengthened focus on intersectionality in the Court's legal interpretation may come under attack. Put differently, can full respect for the principle of nullum crimen sine lege-and particularly its element of specificity_stymie more creative, insightful and adaptable interpretation of the content and scope of mass atrocities (such as acts of genocide and of persecution) on intersecting grounds by placing greater emphasis on intersectional dimensions of a case, as in the Al Hassan confirmation decision? ${ }^{56}$ At first sight, it seems that strict adherence to the principle of legality may stand in the way of actual implementation of intersectionality in the Court's practice. In particular, such an intersectionality-based logic of interpretation and application of substantive law on core crimes of discrimination appears to be in conflict with the provisions of the Rome Statute that enjoin strict and narrow interpretation of crimes and spell out that in case of ambiguity, the definition shall be interpreted in favour of the person being investigated, prosecuted or convicted' (Article 22(2)). How then could the ICC Prosecutor and judges overcome these difficulties in practice - this is, in exercising prosecutorial discretion in the selection of situations and cases, formulation of charges and in adjudicating such cases (notably, in terms of assessing the gravity of a case, sentencing and reparations)? More particularly, how far may the proposed intersectional interpretation and application of international criminal law proceed without interfering with the principle of legality central to the ICC framework?

In addressing these questions, it is first necessary to briefly explain what the principle of legality entails in the context of international criminal law. The legality principle, as nowadays positivized and consecrated in international criminal law and enshrined in the Rome Statute, is not just a substantive rule of this specific area of international law. This principle has also some theoretical and methodological implications on the debates that are at the heart of the

ICC, Le Procureur c. Al Hassan Ag Abdoul Aziz Ag Mohamed Ag Mahmoud, ICC-01/12-01/18, Rectificatif à la Décision relative à la confirmation des charges portées contre Al Hassan Ag Abdoul Aziz Ag Mohamed Ag Mahmoud, La Chambre Préliminaire I, 13 novembre 2019, paras 702,704 and 707 . 
subject matter of this article. What I mean by that is, first of all, the question of how the principle of legality affects the rules of interpretation of international criminal law, but also how it affects, for example, the theory of sources of international criminal law. With this in mind, this section will first set out the quasi-problematic relationship between the principle of legality and legal interpretation that elaborates on intersectional dimensions of mass crimes, before addressing the distinct issue of the applicable rules of interpretation.

Beside developing into an internationally recognized human right which now regulates international criminal law, the principle of legality has also been recognized as constituting a rule of customary international law, as well as a general principle of law. ${ }^{57}$ Moreover, some authors have even suggested that the legality principle is starting to emerge as a new peremptory norm of general international law. ${ }^{58}$ Indeed, the Special Tribunal for Lebanon has endorsed this view by holding that the principle of legality enjoys the status of a norm of jus cogens. ${ }^{59}$ From the outset of this section, it is useful to briefly outline the four most significant dimensions of the principle of legality that are relevant for the further developments of the present discussion. ${ }^{60}$

The first dimension concerns the requirement of nullum crimen sine lege in its broadest sense, meaning that a person cannot be held criminally accountable for certain act or conduct that did not constitute a crime at the time it occurred (Article 22 of the Rome Statute). The second dimension pertains to specificity, certainty and the prohibition of ambiguity in criminal legislation (nullum crimen, nulla poena sine lege certa). This means that crimes must be drafted in detail, that the provision criminalizing a certain act or conduct must be sufficiently precise and the sanction attached to it sufficiently certain. The third dimension includes foreseeability (accessibility). This means that the provision criminalizing a certain act or conduct must be accessible to the alleged perpetrator, so that prosecution for that act or conduct can be foreseeable. The other side of this criterion is that criminal norms and sanctions cannot be applied retrospectively (the principle of nonretroactivity—nullum

57 Claus Kreß, 'Nulla poena nullum crimen sine lege', Max Planck Encyclopedia of Public International Law (2010).

58 Kenneth S. Gallant, The Principle of Legality in International and Comparative Criminal Law (Cambridge University Press, Cambridge, 2008), p. 402.

59 StL, Prosecutor v Salim Jamil Ayyash et al., Case No. STL-11-01/I/AC/R176bis, Appeals Chamber, Interlocutory Decision on the Applicable Law: Terrorism, Conspiracy, Homicide, Perpetration, Cumulative Charging, 16 February 2011, para. 76 .

6o For a more comprehensive study of the various aspects of the principle of legality, see Gallant, supra note 58 . 
crimen, nulla poena sine lege praevia). ${ }^{61}$ The fourth dimension relates to strict interpretation and requires that the definition of a crime be strictly construed, without any extension by analogy (nullum crimen, nulla poena sine lege stricta), and that in case of ambiguity, the interpretation most favourable to the accused shall be adopted (in dubio pro reo). ${ }^{62}$

In response to very creative and far-reaching constructions that international judges at the ad hoc international criminal tribunals put on the definitions of crimes, the ICC chose to ground its jurisdiction on other sources than customary international law. Indeed, the Rome Statute constitutes a more positivistic source of international criminal law and thus in many ways restricts the role of customary international law in the Court's legal framework. ${ }^{63}$ First, the definitions of core international crimes that can be found in the Rome Statute and are further elaborated in the Elements of Crimes are far more extensive and precise. Consequently, there is much less need for the Court to resort to customary international law in order to define the exact meaning and content of the relevant norms. ${ }^{64}$ Second, the ICTY and ICTR statutes explicitly referred to other international treaties such as the Geneva Conventions, with open-ended definitions of specific crimes, whereas the Rome Statute either refrains from this approach or refers to any outside sources with what appears to be exhaustive lists of prohibited acts. ${ }^{65}$ This is especially visible as regards the definitions of specific acts constituting war crimes (Article 8(2)(a) and (c) of the Rome Statute). Third, unlike in the case of ICTY and ICTR, the Rome Statute includes specific provision on the applicable law (Article 21) that, at the same time, determines a hierarchy between the different sources of international law. This provision reserves the primacy for the Rome Statute itself, the Court's Elements of Crimes and its Rules of Procedure and Evidence, while other categories of sources, including international treaties and the principles and rules of international law may only be referred to 'where appropriate'. Such a regulation further reduces the possible scope of applying customary

\footnotetext{
$61 \quad$ Articles 11 and 24 of the Rome Statute.

62 Article 22(2) of the Rome Statute.

63 Leena Grover, 'A Call to Arms: Fundamental Dilemmas Confronting the Interpretation of Crimes in the Rome Statute of the International Criminal Court' 21(3) European Journal of International Law (2010) 543-583, p. 563; Dapo Akande, 'Sources of International Criminal Law', in Antonio Cassese (ed.), The Oxford Companion to International Criminal Justice (Oxford University Press, 2009), pp. 41-53.

64 Dov Jacobs, 'International Criminal Law', in Jörg Kammerhofer and Jean D’Aspremont, International Legal Positivism in a Post-Modern World (Cambridge University Press, Cambridge, 2014) 451-474, p. 466. 
international law by the Court. Indeed, customary international law is not even explicitly mentioned in Article 21 of the Rome Statute as a possible source for the Court to apply, which bespeaks of a marginal position of this traditional source of international criminal law at the Court. ${ }^{66}$

In light of the above statutory provisions, it is hard to disagree with the statement that ICC judges' freedom to liberally and purposively construe the definition of crimes, modes of liability, or defences is rather constrained. ${ }^{67}$ International criminal judges traditionally go about the interpretation of statutory criminal provisions by following two steps. They begin by referring to the general canons of interpretation of international law, as derived from the 1969 Vienna Convention on the Law of Treaties, and then eventually draw on the specific rules and principles of interpretation that flow from the principle of legality and from the criminal law character of the international tribunal concerned. ${ }^{68}$ In view of this common acceptance of the recourse to the rules of interpretation contained in the Vienna Convention on the Law of Treaties, whether through direct application of this Convention or implicitly, it is argued that the existence of the principle legality does not prevent the ICc Prosecutor and judges from their intersectional consideration and intersectionality-sensitive interpretation of mass atrocities in situations and cases before the Court. As is further explained below, this argument can be justified substantially, and a number of explanations can be put forward for favouring more flexible rules of interpretation that would integrate and consolidate intersectionality and its key concepts in the frame of international criminal law.

In practice, the application of the rules of interpretation laid down in the Vienna Convention on the Law of Treaties in interpreting international criminal law statutes may contravene the principle of legality. Dov Jacobs and Dapo Akande have identified at least two such examples: the reference to subsequent practice in Article 31(3) of the Vienna Convention may conflict with the

\footnotetext{
$66 \quad$ Ibid.

67 William A. Schabas, 'Prosecutorial Discretion v. Judicial Activism at the International Criminal Court' 6(4) Journal of International Criminal Justice (2008) 731-761, p. 76o.

68 Jacobs, supra note 64, p. 466-467. For further examples, see William A. Schabas, 'Interpreting the Statutes of the ad hoc tribunals' in Lal Chand Vohrah et al. (eds), Man's Inhumanity to Man: Essays on International Law in Honour of Antonio Cassese (Kluwer Law International, 2003), pp. 847-888, p. 847; Joseph Powderly, 'Judicial Interpretation at the Ad Hoc Tribunals: Method From Chaos' in Shane Darcy and Joseph Powderly (eds), Judicial Creativity at the International Criminal Tribunals (Oxford University Press, 2010), pp. 17-44. STL, Prosecutor v Salim Jamil Ayyash et al., Interlocutory Decision, supra note 59, paras 2732. ICC, Prosecutor v Lubanga, Case No. ICC-o1/o4-168, Appeals Chamber, Judgment on the Prosecutor's Application for Extraordinary Review of Pre-Trial Chamber I's 31 March 2006 Decision Denying Leave to Appeal, 13 July 2006, para. 33.
} 
non-retroactivity requirement of the principle of legality; and the issue of interpreting ambiguities, where, pursuant to Article 32 of the Vienna Convention, ambiguity of a term is to be resolved through the supplementary means of interpretation, while the principle of legality, on the other hand, requires that any ambiguity be resolved in favour of the defendant. ${ }^{69}$

There are two notable reasons that can be put forward to justify more creative and flexible approaches to the interpretation of substantive international criminal law underlying the Court's legal framework, by referring to the relevant provisions of the Vienna Convention of 1969. The first such explanation is that, formally, the Rome Statute is an international treaty. Moreover, the widespread acceptance of the rules of interpretation in the Vienna Convention can also be justified by the reference in the Rome Statute to external sources of international law, such as applicable treaties (Article 21(1)(b)). Indeed, by making the interpretation of the provisions of the Rome statute contingent on the content of the rules of international human rights law and international humanitarian law, the ICC judges were prompted — though, only by way of secondary interpretative practice-to consider and include in their interpretations relevant human rights and humanitarian law treaties themselves. As Dov Jacobs has aptly put it, this "secondary" sources of applicable law before the Court seem to cut off for a moment the connection with the criminal proceedings and consequently with the requirements of the legality principle as well. ${ }^{70}$

A second reason for adopting flexible rules of interpretation in international criminal trials is the fear that by privileging strict and narrow interpretations of statutory provisions a situation of non liquet may arise. The Special Tribunal for Lebanon has expressed its view on this specific aspect of judicial interpretation as follows:

Judges are not permitted to resort to a non liquet (that is, to declare that it is impossible for them to reach a decision because the point at issue 'is not clear' in default of any rule applicable to the case).${ }^{71}$

Indeed, in international criminal trials there is no room for a non liquet outcome when the applicable law is silent or unclear on the point at issue. A vast majority of scholars who have examined in detail the uneasy relationship between the rules of interpretation of the Vienna Convention on the Law of Treaties and the principle of legality have also identified the difficulties in

69 Jacobs, supra note 64, p. 467; Akande, supra note 63, p. 45.

$70 \quad$ Jacobs, supra note 64, p. 468.

$71 \quad$ STL, Prosecutor v Salim Jamil Ayyash et al., Interlocutory Decision, supra note 59, para. 24. 
applying these rules to the particular circumstances of international criminal trials and the requirements of the principle of legality. ${ }^{72}$ Dov Jacobs, however, has challenged the general claim that both modes of interpretation-the one dictated by the rules of the Vienna Convention and that arising from the legality principle-should apply simultaneously, thus bringing about a harmonious result. According to him, international criminal tribunals can only apply those rules of interpretation that are in compliance with the principle of legality. ${ }^{73}$ This, in effect, means that the Vienna Convention cannot be invoked as a source for applicable rules of interpretation, and that any formal reference to this international treaty should therefore be rejected as unacceptable. It is possible to substantiate this somewhat radical, but fundamentally positivistic position in two ways.

A traditional international legal approach in considering this issue is that of lex specialis, meaning that the rules of interpretation contained in the Vienna Convention should only apply in the absence of specific rules of interpretation contained in a specific international treaty or convention. As the principle of legality includes particular requirements for the interpretation of international criminal provisions, it can be seen as operating as a lex specialis in relation to the general rules of interpretation under international law. This line of reasoning thus seems to be especially applicable to the ICC legal framework, given that, as mentioned previously in this section, the Rome statute (as distinct from the ICTY and ICTR Statutes) contains explicit and detailed provisions on interpretation that draw on the principle of legality, including the requirement for strict interpretation, the prohibition of extended interpretation by analogy and the in dubio pro reo principle. ${ }^{74}$

Perhaps more controversial way is that of approaching the issue through the so-called 'functional duality' of the statutes of international criminal courts. ${ }^{75}$ According to this approach, the Rome statute can be considered to be of dual nature - that is, as an instrument not solely determined by its mode of creation, but also by the institutional context in which it is applied. In other words, it can be argued that the Rome Statute contains both rules of international

\footnotetext{
72 Schabas, supra note 68, pp. 847-888; Akande, supra note 63, pp. 41-53; Powderly, supra note 68, pp. 17-44; Grover, supra note 63, pp. 543-583; Beth Van Schaak, 'Crimen Sine Lege: Judicial Lawmaking at the Intersection of Law and Morals', 97 Georgetown Law Journal (2008) 119-192.

73 Jacobs, supra note 64, p. 469.

74 Ibid.

75 Ibid.
} 
law, as the result of a negotiation between states, as well as internal rules when applied in the vertical relationship between the ICC and its member states. ${ }^{76}$

Applied to the ICC, this means that its mode of creation is of secondary importance. The fact that the Rome Statute represents the legislative outcome of international treaty does not mean that the ICC Statute is an international legal instrument in the specific context of the criminal adjudication that it enables. An argument has thus been made that when ICC judges apply the rule and principles of the Rome Statute in international criminal trials, they are not applying them as international treaty provisions proper, but rather as the internal instrument for the functioning of the Court. ${ }^{77}$ This point of view rules out the possibility to refer to the Vienna Convention on the Law of Treaties as providing the rules of interpretation to be applied in criminal proceedings before the Court. However, if there was a disagreement between two or more states parties to the Rome Statute on the interpretation of certain provisions (such as those in Article 98 concerning the immunities of heads of states), the Vienna Convention would be applicable, because the Rome Statute would be considered as a treaty as between the states in dispute. ${ }^{78}$

While these reasons for excluding the Vienna Convention as a method of interpretation are debatable, in relation to international criminal law, it also has to be remembered that its progressive and flexible interpretation is a well-entrenched and necessary part of this distinctive field of international law. This important fact again speaks in favour of prioritizing an interpretative approach that combines the obligation to respect the principle of legality with a general rule of interpretation contained in Article 31 of the Vienna Convention on the Law of Treaties - this is, in good faith in accordance with the ordinary meaning to be given to the terms in their context and in the light of its object and purpose. Accordingly, ICC judges should take into consideration, in the first place, the language of the Rome Statute and, in the second place, the object and purpose of the Rome Statute, as becomes clear from the intention of its drafters. Such a more expansive and purposive- this is, combined textual, contextual and teleological interpretation of the relevant criminal provisions in situations and cases involving intersectional crimes has the potential to properly address root causes of these crimes, and more efficiently remedy their particularly harmful consequences.

Nullum crimen sine lege cannot be understood as disallowing the gradual clarification of international criminal provisions on individual criminal

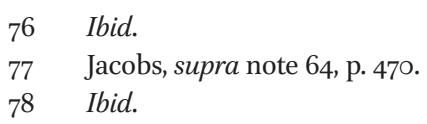


responsibility and on elements of international crimes through more progressive and flexible legal interpretation from case to case, as long as the resultant reasoning is consistent with the essence of the international criminal offence and could reasonably be foreseen. A strong support for this view can be found in the ICTY case law. In Aleksovski, for example, the ICтY Appeals Chamber stated that the principle of legality

does not prevent a court, either at the national or international level, from determining an issue through a process of interpretation and clarification as to the elements of a particular crime; nor does it prevent a court from relying on previous decisions which reflect an interpretation as to the meaning to be ascribed to particular ingredients of a crime. ${ }^{79}$

Having examined the above issues and concerns concerning critical relationship between the principle of legality and legal interpretation that focuses on compound and intersectional dimensions of mass atrocities, the following conclusion can be drawn: the principle of legality does not bar progressive and dynamic interpretation of ICC law trough clarification and application of the concept of intersectional discrimination in the context of mass atrocities, provided that the interpreted law is consistent with the essence of the original crime and could reasonably be foreseen. ${ }^{80}$ In this writer's view, crimes involving elements of discrimination are neither 'frozen' nor resistant to any intersectionality-inclusive interpretation and analysis of relevant criminal provisions. Rather, these provisions are to be interpreted in light of relevant and applicable legal developments in contemporary international human rights law and practice that increasingly seek the ways to inject into and mainstream intersectionality aspects in non-discrimination legislation, policy and litigation. ${ }^{81}$

79 ICту, Prosecutor v Zlatko Aleksovski, Iт-95-14/1-A, Appeals Chamber, Judgment, 24 March 200o, para. 127. The ICTY also adopted this view in Delalić. ICTY, Prosecutor v Zejnil Delalić et al., IT-96-21-A, Appeals Chamber, Judgment, 20 February 2001, para. 173. ICтY, Decision on Dragoljub Ojdanićs Motion Challenging Jurisdiction-Joint Criminal Enterprise, IT-99-37-AR72, Appeals Chamber, 21 May 2003, para. 38.

$80 \quad$ For a concurring view, see Mohamed Shahabuddeen, 'Does the Principle of Legality Stand in the Way of Progressive Development of Law?', 2(4) Journal of International Criminal Justice (2004) 1007-1017, p. 1017.

81 In particular, quasi-judicial bodies tasked with interpreting and monitoring the implementation by States Parties of specialized or thematic human rights treaties relating to equal treatment and non-discrimination with respect to certain groups of people have been, by and large, more inclined to interpret and apply certain provisions, practices and situations in an intersectionality-friendly manner. See the following examples: CERD, General Recommendation No 25: Gender Related Dimensions of Racial Discrimination, 
Against this background, it is difficult to imagine how using intersectionality language to interpret and analyze the relevant criminal provisions, and discussing in greater detail the applicability of the concept of intersectional discrimination to a situation or a case considered by the Court could lead to the interpretation of existing law 'beyond the reasonable limits of acceptable clarification, ${ }^{82}$ and even more difficult, how it could result in the creation of a new unwritten crime or a form of conduct under existing formulations. Therefore, there is no violation of the principle of legality in that solution.

2o March 200o, A/55/18, Annex V, paras 1, 2 and 5; CERD, General Recommendation No 27 on Discrimination against Roma, 16 August 200o, A/55/18, Annex V, para. 6; CEDAW, General Recommendation No 28: The core obligations of State Parties under Article 2 of the Convention on the Elimination of All Forms of Discrimination against Women, 16 December 2010, para. 18; CEDAW, General Recommendation No 25: Article 4, paragraph 1, of the Convention (temporary special measures), 2004, para. 12; CEDAW, General Recommendation No 24: Article 12 of the Convention (women and health), A/54/38 (1999), para. 6; CEDAW, General Recommendation No 33: Women's access to justice, UN Doc. CEDAW/C/ GC/33, 3 August 2015, para. 8; CEDAW, General Recommendation No 34: Rights of rural women, UN Doc. CEDAW/C/GC/34, 4 March 2016, paras 14 and 15; CRC, General Comment No 9: The rights of children with disabilities, UN Doc. CRC/C/GC/9, 27 February 2007, para. 8; CRC, General Comment No. 3: HIV/AIDS and the Rights of the Child, CRC/GC/2003/3, 17 March 2003, paras 7-8; CRPD, General Comment No. 3 on women and girls with disabilities (Article 6), CRPD/C/GC/3, 26 August 2016, para. 16; CRPD, General Comment No 6 on equality and non-discrimination (Article 5), CRPD/C/GC/6, 9 March 2018 (which in several paragraphs expressly mentions intersectional discrimination of particular categories of persons with disabilities); CEDAW Decision 40/I, ConventionSpecific Reporting Guidelines of the Committee on the Elimination of Discrimination against Women, A63/38 (Suppl) part I, Annex I, para. E5; Joint general recommendation No. $3^{1}$ of the Committee on the Elimination of Discrimination against Women/general comment No. 18 of the Committee on the Rights of the Child on harmful practices, CEDAW/C/GC/31-CRC/C/GC/18, 14 November 2014, paras 6 and 15. CEDAW, Alyne da Silva Pimentel Teixeira v Brazil, Communication No. 17/2008, CEDAW/C/49/D/17/2008 (2011), para. 7.7; CEDAw, Cecilia Kell v Canada, Communication No. 19/2008, UN Doc. CEDAW/ C/51/D/19/2008, 26 April 2012, paras 10.2 and 10.3; ACHPR, Egyptian Initiative for Personal Rights (EIPR) and INTERIGHTS v Arab Republic of Egypt, Communication No. 323/2006, Decision, [2011] ACHPR 85, 16 December 2011, paras 152 and 155; IACtHR, Gonzales Lluy et al. $v$ Ecuador, Preliminary objections, merits, reparations, and costs, judgment, September 1, 2015, paras 285 and 29o, and in particular Concurring opinion of Judge Eduardo Ferrer Mac-Gregor Poisot, paras 5-12; ECtHR, B.S. v Spain, application no. 47159/o8, judgment, 24 July 2012, para. 62; ECtHR, Carvalho Pinto de Sousa Morais v Portugal, application no. 17484/15, judgment, 25 July 2017; ECSR, Equal Rights Trust v Bulgaria, Decision on the merits (Complaint No. 121/2016), 16 October 2018, paras 79 and 95. 

Law

For the Court to situate the concept of intersectional discrimination within its legal framework and develop its jurisprudence on intersectionality phenomena in the context of mass atrocities, it is necessary to identify adequate legal basis to do so. Given that the idea of intersectionality is conceptually anchored in equality and non-discrimination as a foundational principle of human rights and the core of human dignity, and that, under the Rome Statute, the Court is bound to apply and interpret all of the applicable law (as hierarchically listed in Article 21) in line with internationally recognized human rights standards as they evolve over time, Article 21(3) may be seen as providing such a legal base. One may thus wonder whether this provision of the Rome Statute can be interpreted and applied so as to guarantee a viable remedy for intersectional violence and discrimination resulting in mass atrocities. Much has already been written about the potential and limits of uses of Article 21(3) of the Rome Statute, ${ }^{83}$ and this section is certainly not the place to propose a general discussion on this issue. Nevertheless, the main argument put forward in this section, namely that this particular provision can serve as useful starting point and principal legal basis for the ICC to effectively invoke when evolving its case law on intersectionality, requires some further explanation.

The Court is pursuant to Article 21(3) of the Rome Statute required to interpret and apply its law in a manner that protects fundamental rights. This is especially true of the Rome Statute itself, as evident from the Court's practice. The ICC Appeals Chamber highlighted this particularly important aspect of legal interpretation, inter alia, in the case concerning Situation in the Democratic Republic of the Congo and in Lubanga, stating that human rights dimensions underlie every single statutory provision. ${ }^{84}$ Such a human rights-oriented approach to ICC law interpretation puts the Court under an

83 See, for example, Stephen Bailey, 'Article 21(3) of the Rome Statute: A Plea for Clarity', 14(3) International Criminal Law Review (2014) 513-550; Ema Irving, "The other side of the Article 21(3) coin: Human rights in the Rome Statute and the limits of Article 21(3), 32(4) Leiden Journal of International Law (2019) 837-850.

84 ICC, Situation in the Democratic Republic of the Congo, ICC-01/04-168, Judgment on the Prosecutor's Application for Extraordinary Review of Pre-Trial Chamber I's 31 March 2006 Decision Denying Leave to Appeal, Appeals Chamber, 13 July 2006, para. 38; ICC, Prosecutor v Thomas Lubanga Dyilo, ICC-01/o4-01/o6-772, Judgment on the Appeal of Mr. Thomas Lubanga Dyilo against the Decision on the Defence Challenge to the Jurisdiction of the Court pursuant to Article 19(2)(a) of the Statute of 3 October 2006, Appeals Chamber, 14 December 2006, para. 37 . 
obligation to go for the interpretation which is congruous with internationally recognized human rights whenever a given rule or principle of law can be interpreted in several different ways. Moreover, if it turns out that certain legal provision violates international human rights law, the Court must not apply it. In other words, all of the law that the Court is entitled to apply, including provisions of the Rome Statute, must be interpreted in line with international human rights instruments, notably those particularly concerned with equality, non-discrimination and human rights of the protected groups and their members. With respect to multiple and intersecting forms of discrimination underlying mass atrocities, this implies that the interpretation and application of the law of genocide, apartheid, persecution and gender-specific crimes should pursue the same rationale and goal as intersectional interpretations in the context of human rights and anti-discrimination law.

Article 21(3) of the Rome Statute, whilst stipulating that human rights must be 'internationally recognized', does not specify what human rights fall under this category. Moreover, the issue of what is to be understood under 'internationally recognized human rights' remains a core point of contention between a number of international legal scholars. It is, however, widely accepted view both in legal scholarship and in international case law that the right to equality and non-discrimination can be considered as one of those fundamental rights that are 'acknowledged by customary international law and international treaties and conventions' ${ }^{85}$ After all, Article 21(3) itself contains an open-ended (this is, non-exhaustive) non-discrimination clause common to most international human rights instruments. It also follows from the ICC case law that the Court frequently bases its legal interpretations and decisions on the pertinent jurisprudence of international and regional human rights bodies, most notably that of the European Court of Human Rights and Inter-American Court of Human Rights. ${ }^{86}$ The Court has in its decisions and judgments moreover referred to other international human rights instruments, including the International Covenant on Civil and Political Rights and the Convention on the Rights of the Child, ${ }^{87}$ as well as some soft law instruments, such as the Basic Principles and Guidelines on the Right to a Remedy and Reparation for

85 ICC, Prosecutor v Lubanga, ICC-01/04-01/06, Appeals Chamber, Decision on the Prosecutor's "Application for Leave to Reply to 'Conclusions de la défense en réponse au mémoire d'appel du Procureur"', 12 September 2006, Separate opinion of Judge Georghios M. Pikis, para. 3 .

86 Gudrun Hochmayr 'Applicable Law in Practice and Theory: Interpreting Article 21 of the ICC Statute', 12(4) Journal of International Criminal Justice (2014) 655-679, p. 675.

87 ICC, Prosecutor v Lubanga, ICC-01/04-01/o6, Trial Chamber I, Judgment, 14 March 2012, para. 604. 
Victims of Gross Violations of International Human Rights Law and Serious Violations of International Humanitarian Law and the Cape Town Principles and Best Practices on the Recruitment of Children into the Armed Forces and on Demobilisation and Social Reintegration of Child Soldiers in Africa. ${ }^{88} \mathrm{~A}$ review of this practice of the Court testifies to the judges' rather broad reading of the concept 'internationally recognized human rights'.

It is also worth noting that the text of Article 21(3) mentions both the interpretation and the application of the law to be applied by the Court under the Rome Statute. This implies that interpreting the ICC law in a manner that promotes human rights will not always suffice, for the Court must also effectively apply human rights. ${ }^{89}$ Conceptually, legal provisions that incriminate core crimes of discrimination such as genocide, apartheid and persecution and make them punishable under international law have particularly strong human rights background and dimensions. Therefore, ICC judges must always carefully consider international human rights standards underlying such provisions. They must consider how international human rights law addresses, for example, violence against women and gender inequality in relation to inter-ethnic conflict. Likewise, the interpretation and application of the law on the crime of incitement to commit genocide or on instigation as a mode of individual responsibility must be led by international human rights law. ${ }^{90}$

It is interesting to point out that the Rome Statute's overarching Article 21(3) on applicable law features prominently in the ICC Prosecutor's policy on sexual and gender-based crimes. ${ }^{91}$ This policy pursues a wide and inclusive understanding of gender-related crimes that takes into account the fact that gender-based crimes are often relational and intersectional with, for example, race, poverty level, ethnic group and age, and links this

88 ICC, Prosecutor v Lubanga, ICC-o1/o4-o1/o6, Trial Chamber I, Decision on Victims' Participation, 18 January 2008, para. 35; ICC, Prosecutor v Lubanga, ICC-01/04-01/o6, Trial Chamber I, Decision Establishing the Principles and Procedures to Be Applied to Reparations, 7 August 2012, para. 185.

89 M. Klamberg (ed.), Commentary on the Law of the International Criminal Court, FICHL Publication Series No. 29, (Torkel Opsahl Academic EPublisher, Brussels, 2017), p. 250; ICC, Prosecutor v Lubanga, ICC-o1/o4-o1/o6 (OA4), Appeals Chamber, Judgment on the Appeal of Mr. Thomas Lubanga Dyilo against the Decision on the Defence Challenge to the Jurisdiction of the Court pursuant to Article 19(2)(a) of the Statute of 3 October 2006, 14 December 2006, para. 37 .

$90 \quad$ ICTR, Prosecutor v Nahimana et al. (Media case), ICTR-99-52, Trial Chamber I, Judgment and Sentence, 3 December 2003, paras 983-999.

91 The Office of the Prosecutor, Policy Paper on Sexual and Gender-Based Crimes (2014), www. icc-cpi.int/iccdocs/otp/policy_paper_on_sexual_and_gender-based_crimes-2o_june_2014eng.pdf, accessed 2 January 2021. 
intersectionality-sensitive framework to Article 21(3). The policy thus acknowledges that, in addition to underlying inequalities, sexual violence and gender-based crimes may intersect with other factors of ethnic, political, religious, national and economic character. ${ }^{92}$ Furthermore, in relation to the substantive law on genocide, crimes against humanity and war crimes and in accordance with Article 21(3) of the Rome Statute the ICC Prosecutor's policy regards multiple factors and forms of discrimination and social inequalities as being interrelated. ${ }^{93}$

For these reasons, the ambit and limits of Article 21(3) of the Rome Statute seem to provide meaningful potential for the Court to conduct an intersectional inquiry into the causes and effects of mass atrocities involving intersectionality phenomena.

\section{$5 \quad$ Conclusion}

This article has discussed some relevant conceptual and legal questions associated with the suggested more holistic and just, that is, intersectional approach of the Court to consideration of situations and cases of mass atrocities involving victims with multiple and intersecting identities. More particularly, it has more closely examined two specific issues germane to the Court's legal framework and related to the suggested implementation and consolidation of the concept of intersectionality in the ICC future jurisprudence: how a more intersectionality-focused interpretative approach to international criminal law may affect the principle of legality (as being central to the ICC framework) and how such an approach could be legally justified and legitimized by the Court. The above discussion enables us to draw some provisional conclusions to which passionate proponents of international legal positivism and especially criminal law positivists, as seen before, could hardly be expected to subscribe. For example, Dove Jacobs has argued that the principle of legality, once positivised, in the field of international criminal law operates largely 'in favour of a more or less strict legal positivism ${ }^{\prime 94}$ and as such should (1) take precedence over the Vienna Convention on the Law of Treaties as providing the pertinent rules of interpretation, and (2) lead to the exclusion of customary international law as a source of this distinctive area of international law. These observations

\footnotetext{
$92 \quad$ Ibid., p. 13.

93 Ibid., p. 16.

94 Jacobs, supra note 64, p. 470.
} 
prompted him to even conclude that the role of international criminal judges is not to 'develop progressively international criminal law, nor to fill interstices and lacuna'. ${ }^{95}$ In my view, the first part of this positivistic claim (the one relating to the law development) is not entirely true. While law development is certainly not the most important function of international criminal judges, it does play a very prominent role in international criminal adjudication, especially when it comes to interpreting and applying human rights, humanitarian and diplomatic law aspects of the international criminal law. As noted earlier, according to Article 21(3) of the Rome Statute human rights considerations should inform and guide the interpretation and application of any aspect of the Court's legal framework, including the statutory provisions encapsulating all the essential elements of the legality principle. This is not to say that any international human rights dictated approach should be adopted in the interpretation and application of substantive international criminal law, that is, even at the expense of restricting the intended effects of the principle of legality. Rather, it means that the dynamic interrelationship and interaction between these bodies of international law that may result in the progressive development of law by international judges cannot simply be dismissed as contravening the principle of legality.

In this concluding section, I would therefore like to put forward the following final considerations. It is true that the ICC legal system with its procedural and evidentiary rules constitutes a highly complex codification of the international criminal law. The Rome Statute, while formally speaking, being an international treaty, comes quite close to the code-based understanding of international criminal law. This is especially true of its specific and elaborated provisions concerning the principle of legality. Indeed, the legality principle (embodied in Articles 22-24 and encompassing non-retroactivity, strict interpretation and prohibition of extension by analogy), along with the Rome Statute's rules on the applicable law (Article 21) favour narrow, ordinary textual (literal) interpretation and application of criminal provisions, including definition of crimes, defences and modes of liability. This means, inter alia, that the legal definitions should not be stretched beyond the text of the Rome Statute and the Elements of Crimes. While these statutory requirements for restrictive legal interpretations reduce the ICC judges' freedom and flexibility to engage in creative and extensive reasoning in the interest of more progressive and dynamic law interpretation, this article has showed that it would be incorrect to say that there is absolutely no room for intersectional consideration of mass atrocities in international criminal law because of the legality 
principle. A more acceptable solution would therefore be the one that actually transposes the philosophy of intersectionality of certain core crimes to international criminal law, and that focuses on human rights dimensions and implications of such crimes in the face of full respect for the principle of legality. As suggested previously, the application of the legality principle which, in general terms, requires that the international criminal procedure by which the guilt or innocence of an individual is determined is fair and impartial is indeed not limited or otherwise affected by this solution.

This central thesis is built on the idea that tends to approach international criminal law in the general context of public international law (as opposed to typical criminal lawyers' view that tends to take, as a starting point, the specificity and differentiation of international criminal law). Naturally, this has certain consequences in the way how one understands the phenomenon of intersectionality (as being originally a human rights issue) in considering the substantive law of genocide, apartheid, persecution and gendered crimes. The first such consequence is that this article has analysed the relevant international criminal law provisions through the lens of general rules and principles of public international law. The second related consequence is that the present article has tended to systematically look at the interrelations and porosity between international criminal law and other bodies of international law, notably human rights law. Moreover, linked to the core argument of this article is the fact that it has focused on questions of unity and coherence of the international legal order as a whole and the progressive development of international (criminal) law. Hence, at least from a normative point of view, the article has espoused a more dynamic interaction between the two fields of international law. This implies that, in the context of international criminal trials, such an understanding is normally also more sympathetic to the application and interpretation of a number of relevant sources of international criminal law. To put it in a nutshell, this article has tended to favour the international law over the criminal law dimension in tackling the issue of intersectionality in the context of the ICC law and practice.

Of course, such preference for the international law approach does not automatically refuse or exclude all considerations of the criminal law dimensions of international criminal law with the flagship principle of legality. Nor does it mean that the general international law approach should not be adapted to the specificities of international criminal law. Also, in adopting an international law approach one should take into consideration the specific history of international criminal law that has evolved in the international context, as compared with domestic criminal law that has developed in the national context. 
This article has moreover taken as a given the existence of a body of international criminal law, functioning as both an international law and a criminal law system. It is within this assumption that I developed my understanding of the relationship between the principle of legality and intersectional (human rights) aspects of some cases of mass atrocities, as well as criticism of the Court's current practice relating to it. While this article has certainly taken a position in favour of the internationally recognized human rights concept of intersectional discrimination as a mediator to the direct and unconditional imposition of the principle of legality, I admit that this does not put an end to the scholarly debate over this thorny issue.

With all these considerations in mind, providing conceptual and legal framework for understanding and analysing intersectionality of mass atrocities in situations and cases before the ICC and assessing the applicability and compatibility of the Court's intersectionality-focused mode of interpretation with such a framework has been the main purpose of this article.

\section{Acknowledgements}

I thank Shai Dothan for many instructive conversations. This article is part of a project that has received funding from the European Union's Horizon 2020 Research and Innovation Programme under grant agreement No 746768 . 